\author{
Barbara Makieła \\ XIII Liceum Ogólnokształcące, Kraków \\ Zbigniew Makiela \\ Zakład Przedsiębiorczości i Gospodarki Przestrzennej \\ Instytut Geografii \\ Akademia Pedagogiczna, Kraków
}

\title{
Nauczanie podstaw przedsiębiorczości w liceach ogólnokształcących i liceach profilowanych
}

Jednym z celów nauczania podstaw przedsiębiorczości jest próba przekształcania systemu kształcenia $\mathrm{w}$ polskich szkołach tak, aby przekazywana wiedza miała w większym stopniu charakter aplikacyjny. Celem jest również przybliżenie młodzieży problematyki przedsiębiorczości, którą należy rozumieć nie tylko w kontekście zakładania firmy, podejmowania działalności gospodarczej, ale przede wszystkim uświadamianie i nauczenie młodych ludzi, że przedsiębiorczość to między innymi:

- umiejętność promowania swojej osoby,

- zdolność nawiązywania kontaktów z otoczeniem,

- asertywność,

- branie odpowiedzialności nie tylko za siebie, ale także za swoją rodzinę, pracowników w swojej firmie,

- zrozumienie otaczającego nas świata,

- $\quad$ zrozumienie zachodzących procesów gospodarczych.

Podejmowane w Polsce reformy strukturalne i programowe systemu szkolnego maja na celu takie przekształcenie systemu szkolnego, aby funkcjonował on na miarę możliwości i potrzeb młodego człowieka oraz na miarę potrzeb współczesnego informacyjnego społeczeństwa, jak najlepiej przygotowując uczniów do życia w tym społeczeństwie. Nowe wyzwania edukacyjne stawia także proces transformacji polskiej gospodarki oraz integracji europejskiej, wymuszający wykształcenie konkurencyjnego, kompetentnego, innowacyjnego i przedsiębiorczego człowieka. Dlatego w zreformowanej szkole wprowadzono nowe treści kształcenia $\mathrm{w}$ ramach nowych przedmiotów, bloków i ścieżek edukacyjnych, w tym przede wszystkim przedmiot podstawy przedsiębiorczości. W założeniach zreformowanej szkoły nauczanie podstaw przedsiębiorczości jako przedmiotu pojawiło się $\mathrm{w}$ liceach profilowanych i liceach ogólnokształcących, technikach i szkołach zawodowych w roku szkolnym 2002/2003.

W liceum profilowanym treści z zakresu przedsiębiorczości są ujęte jako zajęcia edukacyjne o nazwie podstawy przedsiębiorczości, realizowane w ramach kształcenia ogólnego we wszystkich profilach. Treści z zakresu przedsiębiorczości realizowane są także w ramach kształcenia profilowego, w profilach techniczno-technologicznym, środowiskoworolniczym, społeczno-usługowym i kulturowo-artystycznym.

Program nauczania podstaw przedsiębiorczości w kształceniu ogólnym i kształceniu profilowym wynika $\mathrm{z}$ potrzeby całościowego traktowania treści przedmiotu. Nie można oddzielnie nauczać mechanizmów funkcjonowania gospodarki, nie biorąc pod uwagę pod- 
staw decyzji ekonomicznych w firmie czy zarządzania i strategii konkurowania firmy na rynku. Zaletą tak skonstruowanego programu nauczania jest to, że treści podstaw przedsiębiorczości kształcą umiejętności analizy procesów gospodarczych, aktywnego zachowania się na rynku pracy, uczą zakładania własnej firmy, podejmowania ryzyka, planowania własnej kariery.

„Podstawy programowe...” MENiS wyraźnie wyodrębniają treści dotyczące problemów gospodarczych i społecznych Polski, Europy, świata.

Analiza tych problemów powinna odbywać się wielopłaszczyznowo, w odniesieniu do różnego typu układów:

- lokalnego (wsi, miasta, gminy),

- regionalnego (powiatu, województwa, kilku województw),

- $\quad$ krajowego i międzynarodowego.

Szczególnie dużo miejsca w nauczaniu podstaw przedsiębiorczości powinno być przeznaczone na przygotowanie uczniów do aktywnego uczestnictwa w życiu gospodarczym i społecznym. Planowanie kariery zawodowej, kreowanie własnej aktywności zawodowej (w zakresie np. poszukiwania pracy i in.), strategia podejmowania decyzji o utworzeniu własnej firmy (w miejscu zamieszkania - wieś, miasteczko, dzielnica miasta), jest w gospodarce rynkowej umiejętnością najważniejszą. Taki profil kształcenia jest szczególnie przydatny w krajach wprowadzających reguły gospodarki rynkowej, w tym także w Polsce. Zdobycie tych umiejętności jest przydatne w pokonywaniu negatywnych skutków wprowadzania reguł gospodarki rynkowej, między innymi rosnącego bezrobocia. $\mathrm{Z}$ tego między innymi powodu proponowane treści powinny być przedmiotem nauczania już w gimnazjum, a później w liceum ogólnokształcącym, liceum profilowanym, w ramach kształcenia profilowego i kształcenia w szkołach zawodowych. .

Ważne miejsce w nauczaniu powinno zająć przybliżanie uczniom problematyki układów regionalnych, krajowego i międzynarodowego. W celu przygotowania ich do nawiązywania swobodnego kontaktu z otoczeniem, szczególnie międzynarodowym. Powinni poznać uwarunkowania rozwoju regionów, oceniać skutki wpływu otoczenia międzynarodowego na przebieg procesów gospodarczych w ich najbliższym otoczeniu. Znajomość procesów gospodarczych w skali międzynarodowej jest pomocna w wyjaśnianiu podobnych procesów zachodzących w polskiej gospodarce. W okresie integracji Polski z krajami należącymi do Unii Europejskiej konieczne jest poznanie warunków i zasad funkcjonowania tej organizacji. Ponadto ważną kwestią jest zapoznanie się z procesami zachodzącymi w gospodarce regionalnej i globalnej, umiejętność interpretacji przemian społeczno-gospodarczych w Polsce i na świecie, oceny korzyści i zagrożeń wynikających ze współpracy międzynarodowej czy korzystania ze środków pomocowych Unii Europejskiej.

Kolejną kategorię treści przybliża grupa tematów związanych z umiejętnością oceny własnej osobowości i zachowaniami w grupie społecznej. Umiejętności oceny własnych predyspozycji, samorealizacji i kształtowania własnej przyszłości jest ważnym elementem kształcenia, na który nauczyciele przedmiotu powinni zwrócić szczególną uwagę. Spośród wielu relacji interpersonalnych, do istotnych zagadnień należy kształcenie umiejętności właściwego komunikowania się, prowadzenia negocjacji, rozwiązywania problemów międzyludzkich w miejscu pracy, w rodzinie oraz współpracy zespołowej.

Kształcenie i nauczenie w ramach zaproponowanych kanonów ma za zadanie przygotować ucznia do życia w konkurencyjnym społeczeństwie, gdzie zdobyta wiedza i nabyte umiejętności decydują o awansie zawodowym, społecznym i materialnym. Ten typ kształcenia pozwala kreować i promować postawy otwartości, tolerancji, przedsiębiorczości. Współcześnie wykształcony młody człowiek powinien cechować się kreatywnością w miejscu pracy i zamieszkania, twórczo pracować i przekształcać sensownie swoje najbliższe otoczenie.

Warunkiem poprawnego realizowania treści podstaw przedsiębiorczości są właściwie przygotowani nauczyciele, mający ukończone studia wyższe ze specjalnością ,przedsiębior- 
czość”, lub nauczyciele innych przedmiotów, przeszkoleni w zakresie „przedsiębiorczości” na studiach podyplomowych. Potrzeba doskonalenia i poszerzania wiedzy z zakresu podstaw przedsiębiorczości przez nauczycieli wynika $\mathrm{z}$ tego, że podstawowe treści w programie nauczania wymagają specjalistycznej wiedzy i odpowiednich umiejętności formalnych.

W zreformowanej szkole na nauczanie tego przedmiotu w ramach kształcenia ogólnego będzie przypadało 2 godziny tygodniowo. W zależności od decyzji szkoły przedmiot ten może być nauczany w jednej klasie (1 rok kształcenia) w wymiarze 2 godzin lub przez dwie klasy (2 lata kształcenia) w wymiarze 1 godziny tygodniowo. Wydaje się, że przedmiot ten powinien być nauczany przez dwa lata w I i II klasie liceum.

\section{Cele ksztalcenia}

Zgodnie z „Podstawa programową... ” MENiS, mając na uwadze zakładane cele kształcenia, zasadę konwergencji między poszczególnymi etapami kształcenia, a także właściwy kształt programów nauczania i programów wychowawczych szkoły, nauczyciele uczący podstaw przedsiębiorczości wprowadzają uczniów w świat wiedzy o ekonomii, gospodarce Polskiej i światowej, o rynku pracy, przedsiębiorstwie, o roli pieniądza i bankowości, podatkach i ubezpieczeniach. Wdrażają uczniów do samodzielności, pomagają w ocenie własnych predyspozycji i w podejmowaniu decyzji dotyczących wyboru kierunków dalszej edukacji, przygotowania do aktywności zawodowej oraz zakładania i prowadzenia własnej firmy.

Edukacja szkolna na etapie szkoły ponadgimnazjalnej przygotowująca ucznia do aktywnego udziału w życiu gospodarczym i otoczeniu społecznym, winna w szczególności zapewnić uczniom:

- naukę poprawnego i swobodnego wypowiadania się w mowie i w piśmie z wykorzystaniem różnorodnych środków wyrazu,

- umiejętność syntetycznego przekazywania zdobytej wiedzy,

- poznawanie specjalistycznego języka, poszerzanie zakresu wiedzy o nowe pojęcia i twierdzenia,

- stosowanie szerokiego spektrum metod właściwych dla tej dyscypliny,

- dbałość o pozyskiwanie i przekazywanie rzetelnej wiedzy w zakresie umożliwiającym kontynuacje nauki na studiach wyższych,

- przeznaczenie uzyskanej wiedzy na zdobywanie zawodu,

- rozwijanie indywidualnych zdolności ucznia,

- kształcenie liderów,

- uczenie analitycznego myślenia poprzez dostrzegania związków przyczynowo - skutkowych, funkcjonalnych, czasowych i przestrzennych,

- rozwijanie zdolności myślenia abstrakcyjnego,

- integralne traktowanie zdobywania wiadomości i ich egzemplifikacji w relacji do nawyków poznawania świata,

- poznawanie dziedzictwa kulturowego własnego kraju, regionu, „swojej małej ojczyzny”

- wprowadzanie w świat kultury i sztuki, kultury sąsiadów, kultury europejskiej, kultury świata,

- poznawanie zasad rozwoju osobowego i życia społecznego, zdobywanie prawidłowych doświadczeń we współżyciu".

Uczniowie powinni mieć stworzone warunki do nabywania umiejętności:

- planowania, organizowania i oceniania własnej nauki,

- skutecznego porozumiewania się w różnych sytuacjach,

- przygotowania się do wystąpień publicznych,

- efektywnego współdziałania w zespole, budowania więzi międzyludzkich, 
- rozwiązywania problemów w sposób twórczy,

- poznawania źródeł informacji statystycznej,

- poszukiwania i porządkowania informacji, efektywnego posługiwania się komputerami,

- odnoszenia do praktyki zdobytej wiedzy, tworzenia potrzebnych doświadczeń i nawyków,

- rozwijania sprawności umysłowych oraz osobistych zainteresowań,

- przyswajania technik negocjacyjnych, rozwiązywania problemów i konfliktów społecznych.

Uczeń po skończeniu nauki w liceum profilowanym i liceum ogólnokształcącym powinien:

- być przygotowanym do aktywnego i świadomego uczestnictwa w życiu gospodarczym i społecznym,

- rozróżniać podstawowe rodzaje działalności gospodarczej i formy prawne jednostek organizacyjnych prowadzących działalność gospodarczą,

- poznać podstawowe zasady i regulacje prawne i administracyjne prowadzenia działalności gospodarczej,

- poznać prawne mechanizmy sterowania produkcją i obrotem,

- posiąść umiejętność pracy w zespole, skutecznego komunikowania się i negocjacji,

- rozumieć wpływ wytwórczego i usługowego środowiska pracy na zachowanie człowieka,

- mieć umiejętność sprawnego posługiwania się wybranymi przepisami prawa,

- nabyć podstawowe wiadomości i umiejętności z zakresu technologii informacyjnej oraz pracy biurowej,

- umieć aktywnie poszukiwać pracy,

- zaplanować własną karierę zawodową,

- mieć umiejętność planowania, założenia i prowadzenia własnej firmy.

- rozumieć rolę etyki zawodowej w kształtowaniu postaw społecznych,

- przyjmować pozytywne postawy wobec ludzi, szczególnie osób niepełnosprawnych i efektów ich pracy,

- poznać mechanizmy funkcjonowania gospodarki rynkowej oraz rolę państwa i prawa w gospodarce rynkowej,

- poznać zasady funkcjonowania gospodarki europejskiej i światowej, oraz ocenić polską gospodarkę na tle rynku światowego.

W zakresie celów wychowawczych szczególnie istotne jest wspieranie motywacji uczniów tak, by umożliwić im przejmowanie odpowiedzialności za własne życie i rozwój osobowy.

Nauczanie podstaw przedsiębiorczości powinno przyczynić się do:

- rozwoju osobowego w wymiarze intelektualnym, psychicznym, moralnym a także społecznym,

- rozwijania dociekliwości poznawczej, poszukiwania prawdy, dobra i piękna,

- kształtowania odpowiedzialności za siebie i innych, umiejętnego godzenia dobra własnego z dobrem innych,

- odnalezienia własnego miejsca w świecie, realizacja celów życiowych,

- przygotowania do życia w rodzinie, społeczności lokalnej, w państwie,

- rozpoznawania wartości moralnych i umiejętności ich hierarchizacji,

- kształtowania postaw dialogu, umiejętności słuchania innych.

Ogólnie można stwierdzić, że celem edukacji podstaw przedsiębiorczości w liceach i szkołach zawodowych, jest wszechstronny rozwój młodego pokolenia Polaków, ułatwianie im zrozumienia otaczającego świata, znalezienia swojego miejsca w społeczności lokalnej. Ponadto: budowanie systemu wartości zgodnych z normami społecznymi, przestrzeganie 
i propagowanie systemu wartości we współżyciu rodzinnym, społeczności lokalnej, a także na poziomie krajowym i w ramach współpracy międzynarodowej.

\section{TREŚCI NAUCZANIA}

Uwzględniając przedstawione cele edukacyjne, treści nauczania w liceum profilowanym i liceum ogólnokształcącym powinny zawierać (Makieła, Rachwał 2002):

1. ISTOTA FUNKCJONOWANIA GOSPODARKI. Do treści szczegółowych należy zaliczyć:

- Przemiany gospodarcze w Polsce.

- Systemy gospodarcze, system gospodarki rynkowej, system nakazowo rozdzielczy.

- Gospodarka centralnie sterowana. Gospodarka rynkowa.

- Funkcjonowanie rynku. Rola państwa w gospodarce rynkowej.

- Podstawowe funkcje ekonomiczne państwa.

- Prywatyzacja, reprywatyzacja, restrukturyzacja, demonopolizacja.

- Polityka fiskalna i monetarna Polski.

- Wzrost gospodarczy. Dynamika wzrostu. Stagnacja gospodarcza. Kryzys gospodarki.

- Dochód narodowy. Produkcja globalna. Produkt Krajowy Brutto (PKB).

- Struktura dochodu. Struktura produkcji.

- Struktura towarowa handlu zagranicznego.

- Zjawiska makroekonomiczne. Mierniki makro- i mikroekonomiczne.

- Klasyfikacje gospodarki. Dział produkcyjny i dział nieprodukcyjny.

- Podstawowe podmioty w gospodarce rynkowej. Gospodarstwa domowe. Przedsiębiorstwa. Spółki.

- Banki. Bank Centralny.

- Giełda papierów wartościowych. Notowania giełdowe. Parkiet. Spółki giełdowe. Akcje. Kursy akcji. Kurs zamknięcia, kurs otwarcia. Indeks giełdowy.

- Budżet państwa. Budżet jednostek samorządu terytorialnego. Ustawa budżetowa. Okres budżetowy. Budżet zrównoważony. Deficyt budżetowy. Wydatki budżetowe. Dochody budżetowe. Źródła wpływów.

- Budżet domowy.

- Źródła informacji gospodarczej. Roczniki statystyczne. Internet. Czasopisma i wydawnictwa gospodarcze. Publikowane wyniki finansowe spółek.

2. UMIEJĘTNOŚCI INTERPERSONALNE. Do treści szczegółowych należy zaliczyć:

- Poznanie własnej osobowości. Asertywność. Ocena własnych predyspozycji do pracy zawodowej i prowadzenia działalności gospodarczej.

- Motywy aktywności zawodowej. Postawa przedsiębiorcza.

- Komunikacja z ludźmi. Rodzaje komunikatów.

- Pokonywanie barier w procesie komunikacji.

- Prowadzenie negocjacji i rozwiązywanie konfliktów. Radzenie sobie ze stresem.

- Umiejętność praca zespołowej. Podejmowanie decyzji i kierowanie zespołem.

- Postępowanie etyczne, przeciwdziałanie korupcji.

3. PRACA. Do treści szczegółowych należy zaliczyć:

- Rola pracy w gospodarce i społeczeństwie. Sens pracy. Praca jako wartość.

- Sens inwestowania w siebie. Rozwój własnej osobowości.

- Zdobywanie doświadczenia zawodowego i dodatkowych umiejętności.

- Problemy bezrobocia. Ekonomiczne i psychologiczne aspekty utraty pracy.

- Instytucje pomagające poszukującym pracy. Formy pomocy bezrobotnym.

- Metody poszukiwania pracy. 
- List motywacyjny, CV. Rozmowa kwalifikacyjna.

- Podstawy prawne zatrudnienia.

- Umowa o pracę.

- Prawa i obowiązki pracownika i pracodawcy. Umowy cywilno-prawne.

- Bezpieczeństwo i higiena pracy. Wynagrodzenie za pracę.

- Specyfika pracy osób niepełnosprawnych.

4. PRZEDSIĘBIORSTWO. Do treści szczegółowych należy zaliczyć:

- Rodzaje działalności gospodarczej.

- Przesłanki wyboru rodzaju działalności.

- Klasyfikacja przedsiębiorstw.

- Formy organizacyjno-prawne podmiotów gospodarczych.

- Procedura zakładania własnej firmy. Rejestracja firmy.

- Planowanie działalności gospodarczej. Biznes plan.

- Wybór miejsca lokalizacji firmy.

- Analiza rynku.

- Źródła finansowania działalności.

- Podstawowe rodzaje działań marketingowych. Reklama. Sprzedaż.

- Zasady obsługi klienta. Prawa konsumenta.

- Finanse firmy. Koszty i zasady rozliczeń finansowych w firmie.

- Majątek firmy. Kapitał własny. Kredyty, pożyczki, zobowiązania. Joint-venture.

- Organizacja pracy. Zarządzanie firmą.

- Zasady prowadzenie dokumentacji firmy, księgowość, dokumentacja zatrudnienia pracowników.

- Restrukturyzacja działalności firmy. Likwidacja firmy, procedury likwidacyjne.

5. PIENIĄDZ I BANKOWOŚĆ. Do treści szczegółowych należy zaliczyć:

- Funkcja i podaż pieniądza.

- System bankowy. Funkcja banku centralnego.

- Inflacja. Stopy procentowe. Kursy walutowe

- Funkcjonowanie banków komercyjnych.

- Rachunek bankowy. Debet.

- Karty płatnicze.

- Czeki. Polecenie przelewu.

- Lokaty bankowe złotowe i walutowe. Oprocentowanie lokat.

- Kredyty, kryteria zdolności kredytowej. Oprocentowanie kredytu. Weksle.

- Pozabankowe usługi finansowe. Leasing. Fundusze inwestycyjne.

6. PODATKI I UBEZPIECZENIA. Do treści szczegółowych należy zaliczyć:

- Sens płacenia podatków.

- Rodzaje podatków. Podatki bezpośrednie i pośrednie. Podatki dochodowe, VAT, akcyza, podatki lokalne.

- Deklaracje podatkowe. Roczne rozliczenia podatku dochodowego od osób fizycznych. Podstawowe deklaracje podatkowe firmy.

- Ulgi w podatku dochodowym od osób fizycznych.

- Ulgi podatkowe dla przedsiębiorstw, w tym z tytułu zatrudniania osób niepełnosprawnych.

- Ubezpieczenia społeczne. Reforma ubezpieczeń w Polsce. I, II i III filar ubezpieczeń. Ubezpieczenia zdrowotne.

- Ubezpieczenia dobrowolne. Ubezpieczenia majątkowe. Ubezpieczenia OC. Polisy na życie. 
7. MIĘDZYNARODOWA WSPÓŁPRACA GOSPODARCZA. Do treści szczegółowych należy zaliczyć:

- Współpraca gospodarcza Polski z zagranicą. Handel zagraniczny, kierunki, natężenie.

- Integracja z Unią Europejską. Fundusze pomocowe i ich wykorzystanie. Budżet UE.

- Współpraca w ramach międzynarodowych organizacji gospodarczych, CEFTA.

- Współpraca euroregionalna. Bariery współpracy euroregionalnej.

- Proces globalizacji i jego konsekwencje.

- Szanse i zagrożenia współpracy międzynarodowej.

\section{OSIĄGNIĘCIA UCZNIÓW}

Przedstawione $\mathrm{w}$ Rozporządzeniu MENiS programowe treści nauczania umożliwią realizację osiągnięć uczniów, które określone zostały w następujący sposób:

- identyfikacja podstawowych mierników wzrostu gospodarczego (PKB, PNB - nominalny i realny oraz w przeliczeniu na 1 mieszkańca).

- identyfikowanie podstawowych praw i uwarunkowań funkcjonowania mechanizmu rynkowego z punktu widzenia konsumenta i producenta.

- znajomość wpływu polityki fiskalnej i monetarnej na życie gospodarcze kraju.

- rozróżnianie aktywnych i pasywnych form polityki państwa skierowanej na łagodzenie skutków oraz przeciwdziałanie bezrobociu i inflacji.

- interpretowanie podstawowych wskaźników inflacji.

- umiejętność identyfikacji podstawowych form własności oraz form organizacyjno prawnych przedsiębiorstw.

- rozróżnianie form inwestowania, wyjaśnianie zależności pomiędzy zyskiem a ryzykiem.

- znajomość procedury postępowania w celu uruchomienia działalności gospodarczej.

- umiejętność rozpoznania potrzeb rynku lokalnego w kontekście przyszłej działalności gospodarczej.

- umiejętność przygotowania biznes planu i wybór miejsca działalności gospodarczej.

- znajomość strategii zarządzania firmą oraz zasad organizacji pracy.

- umiejętność przygotowania dokumentów niezbędnych w procesie poszukiwania i podejmowania pracy. Znajomość procedur związanych z poszukiwaniem pracy.

- umiejętność autoprezentacji i samooceny z uwzględnieniem predyspozycji do podejmowania działalności zawodowej.

- przygotowanie i prowadzenie rozmowy kwalifikacyjnej z pracodawcą w warunkach symulowanych.

- znajomość obowiązków pracownika i pracodawcy oraz praw i obowiązków osoby bezrobotnej i poszukującej pracy.

- umiejętność stosowania i doboru odpowiednich technik i zasad pracy w zespole i prowadzenia negocjacji.

- umiejętność określania opłacalności działalności gospodarczej w kontekście wydatków i przychodów, zysku i ryzyka.

- identyfikowanie instytucji będących źródłem informacji gospodarczej i wspomagających działalność małych i średnich przedsiębiorstw na lokalnym rynku.

- wskazywanie korzyści i zagrożeń współpracy międzynarodowej, współpracy gospodarczej z zagranicą.

- umiejętność korzystanie ze środków pomocowych Unii Europejskiej. 


\section{Procedury OSIĄGANia CELów KSZTALCENIA}

Nowy przedmiot nauczania $\mathrm{w}$ liceach profilowanych i liceach ogólnokształcących podstawy przedsiębiorczości - ma przygotowywać do życia w nowych warunkach społeczno-gospodarczych, uczyć samodzielności i podejmowania decyzji o swoich losach. $\mathrm{Z}$ tego między innymi powodu przywiązuje się wielką wagę do kształtowania w uczniach różnorodnych umiejętności z zakresu przedsiębiorczości i umiejętności formalnych, a także przekonań, nawyków, zachowań i postaw. Realizacja umiejętności wymaga od nauczyciela, głównego organizatora procesu kształcenia, zastosowania takich metod nauczania, które dają najlepsze wyniki, które pozwalają najlepiej osiągnąć przez uczniów zakładane cele.

Małą przydatność w tym zakresie mają metody powszechnie stosowane, tj. metody asymilacji wiedzy (metody podające, metody słowne), jak opis, opowiadanie, wykład, pogadanka, praca z książką, dlatego należy je ograniczyć do minimum. Większą przydatność mają metody samodzielnego dochodzenia do wiedzy, dyskusja, obserwacja i pomiar, metoda problemowa, gry dydaktyczne, metoda studiów przykładowych (sample study).

Dyskusja jest metodą kształcenia, polegającą na wymianie poglądów między nauczycielem a uczniami lub pomiędzy uczniami. W dyskusji można posługiwać się zapożyczonymi poglądami od innych osób, wygłaszać własne poglądy. Cechą dyskusji jest zawarty w niej element twórczy, związany z odmiennością stanowisk dyskutantów, szukaniem optymalnego stanowiska możliwego do przyjęcia przez większość dyskutantów, korekta poglądów. Dyskusja służy kształtowaniu postaw samodzielności, autoprezentacji, szacunku dla odmiennych poglądów, a także obiektywizmu w ocenie faktów i zdarzeń. Przygotowując lekcję z zastosowaniem metody dyskusji, nauczyciel powinien podzielić klasę na grupy, wtedy w dyskusji aktywnie uczestniczą wszyscy uczniowie, a nie tylko pojedyncze osoby, mogą wtedy swobodnie przedstawiać swoje poglądy w grupie. Na forum klasy przedstawiane są wyniki dyskusji uzgodnione w grupach, co pozwala na uzgodnienie poglądów. Przy metodzie dyskusji należy stosować metody aktywizujące uczniów, takie jak burza mózgów, ranking diamentowy, drzewo decyzyjne, metaplan.

Skuteczność i efektywność kształcenia w zakresie podstaw przedsiębiorczości umożliwia także metoda obserwacji i pomiaru, która polega na planowym i świadomym spostrzeganiu przedmiotów, zjawisk i procesów. Realizacja programu nauczania przy pomocy obserwacji i pomiaru może odbywać się bezpośrednio w banku, urzędzie, przedsiębiorstwie (obserwacje bezpośrednie), jak też w sali lekcyjnej (obserwacje pośrednie). Spostrzeżeń dokonują uczniowie, a rola nauczyciela sprowadza się do stwarzania okoliczności obserwacji, jej ukierunkowywanie, pomoc w rejestrowaniu i interpretacji wyników.

Aby obserwacje były skuteczne, należy spełnić następujące warunki:

- należy ustalić przedmiot i cel obserwacji,

- wyposażyć uczniów w podstawową wiedzę o obserwowanym obiekcie,

- wydzielić precyzyjnie obserwowany przedmiot, zjawisko, zdarzenie,

- skupić uwagę na przedmiocie obserwacji,

- rejestrować zmiany zachodzące w obserwowanym obiekcie,

- dokonać pomiaru i rejestracji cech diagnostycznych obserwowanego obiektu,

- opisać obiekt i jego charakterystykę,

- wywołać u uczniów emocjonalny stosunek do obserwowanego obiektu,

- zanalizować na lekcji zdarzenia wynikłe podczas obserwacji i pomiaru.

Kolejną zalecaną metodą dla osiągnięcia celów kształcenia jest metoda problemowa. Jak podaje amerykański pedagog J. Dewey, w metodzie tej występują następujące ogniwa rozwiązywania problemu: odczucie trudności - wykrycie ich i określenie - nasuwanie się możliwego rozwiązania - wyprowadzenie wniosków z przypuszczalnego rozwiązania obserwacje i eksperymenty sprawdzające przypuszczenie.

Przy stosowaniu metody problemowej należy uwzględnić następujące etapy: 
- tworzenie sytuacji problemowej,

- formułowanie problemu i pomysłów jego rozwiązania,

- rozwiązywanie problemu,

- weryfikacja rozwiązania,

- uogólnianie wniosków (consensus).

Metoda problemowa pozwala pobudzić uczniów do samodzielności nie tylko przy rozwiązywaniu problemów, ale także w ich formułowaniu.

Kolejną zalecaną metodą osiągnięcia celów kształcenia w zakresie podstaw przedsiębiorczości są gry dydaktyczne. Najlepsze rezultaty w zakresie celów kształcenia osiąga nauczyciel stosując gry dydaktyczne typu strategicznego, tj. gry w giełdę pomysłów (burza mózgów, fabryka pomysłów), gry sytuacyjne (metoda przypadków), gry symulacyjne. Metoda ta pozwala na osiągnięcie zachowań operacyjnych uczniów, spontaniczności, kreowanie liderów, określanie hierarchii wartości.

Metoda studiów przykładowych (sample study) jest dość powszechnie stosowana w nauczaniu problematyki gospodarczej w szkołach zachodnioeuropejskich i amerykańskich. Metoda ta kładzie nacisk na samodzielne dochodzenie uczniów do nowej wiedzy w oparciu o badania terenowe, materiały źródłowe (źródła statystyczne, mapy, fotografie, ryciny), obiekty, zjawiska, procesy. Ważny elementem tej metody jest to, by w studium przykładowym po szczegółowym przestudiowaniu przedmiotu poznania, były sformułowane wnioski. Wnioski muszą mieć charakter uogólniający, muszą się odnosić do grupy przedmiotów, większego zbioru zdarzeń, szerszego procesu. Zastosowanie tej metody pozwala pobudzić zainteresowania uczniów, ułatwia poznawanie. Studia przykładowe służą tworzeniu wyobrażeń, kształtowaniu pojęć, odkrywaniu zależności oraz formułowaniu prawidłowości i teorii wyjaśniających.

Osiąganie celów kształcenia w nauczaniu podstaw przedsiębiorczości wymaga zastosowania metod praktycznych, które umożliwiają nabywanie umiejętności praktycznych związanych z otaczającą rzeczywistością. Ponadto wpływają na świadomość ucznia, decydują o jego umiejętności radzenia sobie w konkretnych sytuacjach (np. napisanie listu motywacyjnego, wypełnienie przekazu bankowego, formularza PIT i in.), przekonania o swoich możliwościach i aktywnej postawie. Metody te dzielimy na dwie grupy, ćwiczenia techniczne i terenowe oraz metody służące realizacji zadań wytwórczych i usługowych.

Podstawy przedsiębiorczości, obok wiedzy merytorycznej z zakresu podstaw ekonomii, elementów wiedzy o gospodarce i polityce społecznej muszą kształcić umiejętności podejmowania decyzji, decydowania za siebie, odpowiedzialności za swoich najbliższych, pracowników swojej przyszłej firmy, uczyć samodzielności i kreatywnego myślenia. Z tego $\mathrm{m}$.in. powodu zalecane jest częste organizowanie samodzielnej pracy uczniów w grupach.

Już od początku edukacji z zakresu podstaw przedsiębiorczości konieczne jest stosowanie metod, wymagających od uczniów samodzielnego podejmowania decyzji i oceny atrakcyjności poszczególnych rodzajów działalności gospodarczej, umiejętności korzystania i wyboru źródeł informacji gospodarczej (roczniki statystyczne). W dalszym etapie kształcenia uczniowie muszą posiąść wiedzę z zakresu rozwiązywania konfliktów społecznych, prowadzenia negocjacji i doboru ludzi do współpracy.

Kolejnym bardzo istotnym krokiem na drodze edukacji, zmierzającym do samodzielności, jes umiejętność założenia własnej firmy, zarządzania nią, poznawania rynku, na którym ma działać. Może się to odbywać na dobranych odpowiednio przykładach zaczerpniętych z życia gospodarczego w najbliższym otoczeniu, lub przykładów z literatury przedmiotu.

Samodzielna praca ucznia z podręcznikiem, informacje z telewizji, radia, prasy, z zakresu gospodarki, polityki społecznej, zachowań podmiotów gospodarczych i instytucji samorządowych, oraz wiadomości uzyskiwane z literatury popularnonaukowej, stawiają przed nauczycielem kolejne zadania. Najważniejsze to pomoc uczniom we właściwej selekcji in- 
formacji, w zrozumieniu języka publicystycznego, syntezie informacji jednostkowych, holistycznym traktowaniu problemów gospodarczych i społecznych, wyrabianiu własnej oceny na dany temat.

Metody samodzielnej pracy uczniów służą nie tylko zdobywaniu wiedzy i umiejętności z zakresu przedsiębiorczości, ale także zdobywaniu i rozwijaniu umiejętności formalnych, np. porównywania, analizowania, syntetyzowania, wnioskowania redukcyjnego, dedukcyjnego i indukcyjnego.

Prawidłowa realizacja programu nauczania podstaw przedsiębiorczości wymaga przygotowania merytorycznego (ukończone studia podyplomowe z zakresu przedsiębiorczości) i metodycznego nauczycieli (zapoznanie się z podręcznikiem i przewodnikiem do nauczania podstaw przedsiębiorczości, np. Makieła, Rachwał 2003) i stosowania właściwych środków dydaktycznych w pracy z uczniem, w tym:

- podręcznika podstaw przedsiębiorczości (np. Makieła, Rachwał 2005a),

- zeszytu ćwiczeń, jako integralnej części podręcznika (np. Makieła, Rachwał 2005b),

- słownika szkolnego podstaw przedsiębiorczości (np. Rachwał 2004),

- multimedialnego CD-ROM podstaw przedsiębiorczości (np. Śrutowska, Rachwał 2005)

- roczników statystycznych,

- $\quad$ komputera $\mathrm{z}$ odpowiednim oprogramowaniem i dostępem do Internetu;

- $\quad$ katalogu książek i czasopism o treści gospodarczej, dostępnych w bibliotece szkolnej.

\section{SPRAWDZANIE OSIĄGNIĘĆ UCZNIÓW (STANDARDY KSZTALCENIA)}

Wdrażanie reformy systemu edukacji ma na celu m.in. zmianę kryteriów oceny osiągnięć uczniów. Ważnym celem tej reformy jest wprowadzenie do praktyki szkolnej jednolitych, czytelnych kryteriów oceny ucznia. Oceny ucznia na świadectwie szkolnym mają być porównywalne na terenie całego kraju. Znaczy to, że proponowany system oceniania ma doprowadzić do unifikacji i możliwości porównywania poziomu kształcenia w szkołach wiejskich, w szkołach miejskich i pomiędzy nimi, a co za tym idzie system ten ma prowadzić do wyrównywania poziomu kształcenia na terenie całego kraju. Kolejnym celem, który powinien być zrealizowany w omawianym zakresie jest to, że kryteria oceny ucznia mają także odpowiadać standardom obowiązującym w krajach Unii Europejskiej. Oznacza to, że w niedługiej perspektywie świadectwa ukończenia szkoły w Polsce będą porównywalne na terenie całej Unii Europejskiej.

W liceum profilowanym i liceum ogólnokształcącym osiągnięcia uczniów (pośrednio także nauczycieli) kontrolowane są w dwóch płaszczyznach: przeprowadzana jest kontrola i ocena wewnątrzszkolna oraz ocena i kontrola zewnętrzna. W przypadku kontroli wewnątrzszkolnej, oceny dokonuje nauczyciel przedmiotu. Celem kontroli jest uświadamianie uczniom skali i stopnia opanowania wiedzy, umiejętności, ale także braków i niedociągnięć. Kontrola pozwala także dyscyplinować proces realizacji programu przez uczniów i nauczyciela, jest ważnym źródłem informacji o efektywności stosowanych metod kształcenia, uzyskanych efektów w klasie i u poszczególnych uczniów. Nauczyciel i uczniowie poznają skalę zróżnicowania wiedzy, różnice pomiędzy liderami a uczniami słabszymi w klasie.

Przy przeprowadzaniu kontroli obowiązkiem nauczyciela jest poinformowanie uczniów i określenie skali wymagań wynikających z realizacji programu, określenie sposobów kontroli i kryteriów oceny osiągnięć uczniów. W przypadku wyrażenia życzenia przez rodziców, o zasadach kontroli nauczyciel powinien ich także poinformować.

Zgodnie z celami kształcenia, przedmiotem kontroli powinien być nie tylko stan wiedzy uczniów, lecz ich postępy w zakresie umiejętności. Kontrola i ocena mają odzwierciedlać nie tylko wiedzę merytoryczną ucznia, często rozumianą jako zapamiętanie definicji, faktów, liczb, czyli nie to co uczeń wie, lecz co pamięta. Ocena ma odzwierciedlać przede 
wszystkim to, co uczeń potrafi dobrze wykonać, czy potrafi wyciągać wnioski z podanych zdarzeń, faktów, czy potrafi samodzielnie myśleć.

\section{LITERATURA}

Makieła Z., Rachwał T., 2002, Podstawy przedsiębiorczości. Program nauczania dla liceum ogólnokształcącego, liceum profilowanego i technikum, Wydawnictwo Nowa Era. Warszawa

Makieła Z., Rachwał T., 2003, Podstawy przedsiębiorczości. Poradnik metodyczny dla nauczycieli liceum ogólnokształcacego, liceum profilowanego i technikum. (wydanie drugie zm.), Wydawnictwo Nowa Era. Warszawa

Makieła Z., Rachwał T., 2005a, Podstawy przedsiębiorczości. Podręcznik dla liceum ogólnoksztatcacego, liceum profilowanego i technikum (wydanie czwarte zm.), Wydawnictwo Nowa Era. Warszawa.

Makieła Z., Rachwał T., 2005b, Podstawy przedsiębiorczości. Zeszyt ćwiczeń dla liceum ogólnoksztatcacego, liceum profilowanego i technikum. (wydanie czwarte zm.), Wydawnictwo Nowa Era. Warszawa

Makieła Z., 2004, Nowy przedmiot nauczania dla geografów - podstawy przedsiębiorczości [w:] Kształcenie i dokształcanie nauczycieli geografii w Polsce i w krajach Unii Europejskiej w drodze do jednoczącej się Europy, red. W. Osuch i D. Piróg, Wyd. Naukowe AP, Kraków

Podstawa programowa kształcenia ogólnego (dla liceum ogólnoksztatcacego, liceum profilowanego i technikum), Rozporządzenie Ministra Edukacji Narodowej i Sportu z dn. 26 lutego 2002 r., Warszawa

Podstawy przedsiębiorczości. Scenariusze zajęć edukacyjnych dla liceum ogólnokształcacego, liceum profilowanego i technikum, praca zbiorowa, 2003, Wydawnictwo Nowa Era. Warszawa

Rachwał T., 2004, Podstawy przedsiębiorczości. Stownik dla liceum ogólnoksztatcacego, liceum profilowanego i technikum. Wydawnictwo Nowa Era. Warszawa

Rachwał T. 2004, Ksztaltowanie postaw przedsiębiorczości u uczniów wyzwaniem dla nauczycieli geografii [w:] Kształcenie i dokształcanie nauczycieli geografii w Polsce i w krajach Unii Europejskiej w drodze do jednoczącej się Europy, red. W. Osuch i D. Piróg, Wyd. Naukowe AP, Kraków

Rachwał T., 2004, Cele i treści kształcenia przedsiębiorczości w szkołach ponadgimnazjalnych, [w:] Przedsiębiorczość stymulatorem rozwoju gospodarczego, red. J. Brdulak i M. Kulikowski, Instytut Wiedzy, Warszawa

Śrutowska D., Rachwał T. (red.), 2005, Podstawy przedsiębiorczości. Multimedialny CD-ROM dla liceum ogólnoksztatcącego, liceum profilowanego i technikum. Wydawnictwo Nowa Era, Young Digital Poland, Warszawa-Gdańsk. 